\title{
Financial Development and Poverty in Developing Countries: Evidence from Sub-Saharan Africa
}

\author{
Pam Zahonogo ${ }^{1}$ \\ ${ }^{1}$ Université Ouaga II, Burkina Faso \\ Correspondence: Pam Zahonogo, Université Ouaga II, 03 BP 7164, Ouagadougou 03, Burkina Faso. Tel: \\ 226-7026-8113/226-7824-1124. E-mail: pzahonogo@gmail.com
}

Received: September 21, 2016

Accepted: December 18, 2016 Online Published: December 20, 2016

doi:10.5539/ijef.v9n1p211

URL: http://dx.doi.org/10.5539/ijef.v9n1p211

\begin{abstract}
The paper investigates how financial development affects poverty indicators in developing countries. We implement this analysis with a poverty model using data from 42 Sub-Saharan African countries and covering the period 1980-2012. We employ the System Generalized Method-of-Moment (GMM) that is appropriate to control country specific effects and the possible endogeneity. The empirical evidence shows that there indeed exists a financial development threshold below which financial development has detrimental effects on poor and above which financial development could be associated with less poverty. The evidence then points an inverted $\mathrm{U}$ curve type response and the findings are robust to changes in poverty measures and to alternative model specifications, suggesting thus the non-fragility of the linkage between financial development and poverty for sub-Saharan African countries. Our findings are then promising and support the view that the relation between financial development and poverty reduction is not linear for sub-Saharan African countries.
\end{abstract}

Keywords: financial development, poverty, Sub-Saharan Africa

\section{Introduction}

Poverty reduction represents a major challenge for all countries and specifically for developing ones. The international organizations such as World Bank and the International Monetary Fund have incorporated the objective of poverty reduction in most of their development programs. Therefore, and to fight against this scourge, priority was given to pro-growth policies because it has been shown that countries whose experienced high rates of economic growth are those that are managed to reduce their poverty rates. Since the seminal work of McKinnon (1973) and Shaw (1973), economists generally consent that financial development enhances economic growth. Africa remains the poorest continent of the world. Yet, at the same time, Sub-Saharan Africa countries have experienced improvements in financial development. It seems that the large gains expected from developed financial sector have, to date, been limited in Africa, especially for poor people.

The relationship between financial development and poverty reduction has generated a substantial and inconclusive literature both theoretical and empirical fronts in recent years. Theory provides conflicting predictions while empirical results have been equally mixed. Some claim that, by allowing more entrepreneurs to obtain financing, financial development improves the allocation of capital, which has a particular large impact on the poor while others argue that it is primarily the rich and the politically connected who benefit from improvements in the financial system (Singh \& Huang, 2015).

Theoretically, financial development may affects poverty through two channels. The first channel shows that financial development affects poverty directly by improving the access of the poor to financial services (Odhiambo, 2009; Pradhan, 2010; and Akhter et al., 2010). The second channel indicates that financial development affects poverty indirectly by stimulating economic growth through increased investment rates (King \& Levine, 1993; Levine, 2005). There seems to be an implicit assumption in existing research that if financial development improves growth, then this automatically translates into reduction in poverty. But some argue that financial development has been identified as cause of financial crisis and an unstable macroeconomic environment (Kaminsky \& Reinhart, 1999) and these have been identified as detrimental to the poor (Easterly \& Fischer, 2001). Theoretical poverty studies suggest at best a very complex relationship between financial development and poverty reduction. 
Like theoretical analyses, the empirical literature on the interaction between financial development and poverty provides mostly inconclusive findings. Some studies argue that financial development has a strong positive impact on the income of the poor and contribute to poverty reduction (Jallian \& Kirkpatrick, 2002; Honohan, 2004; Beck et al., 2007; Odhiambo, 2009; Boukhaten \& Bochra, 2012) while others find that financial development does not affect the poor (Dollar \& Kraay, 2002; Fowowe \& Abidoye, 2012). Clarke et al. (2003) opined that there is a negative relationship between financial development and income inequality rather than an inverted-U shaped relationship suggested by Greenwood and Jovanovick (1990).

The lack of clear correlation between financial development and poverty could be because financial development almost certainly requires combination with other appropriate policies that encourage access to financial services and investment for poor, allow effective conflict resolution and promote human-capital accumulation. So, institutions can help explain the heterogeneity in financial development-poverty relationship. On policy perspective, since financial sector reform is frequently addressed in policy prescription packages by World Bank and International Monetary Fund to enable poor accessing financial services, it is important to know how and through which mechanisms financial development affects poverty alleviation. The main policy conclusion is that a poverty reduction strategy should not be based solely on financial development, but also on good macroeconomic policies and efficient institutions, which seem to be more robust in poverty regression.

The contribution of this paper is to assess if the relation between financial development and poverty differs between more developed and less developed financial sector. Such distinction is important as there are theoretical models and empirical results suggesting that there was a certain threshold level of financial development that an economy need to attain before it can get the full indirect benefit to reduce poverty. Particularly for developing countries, the lack of investment in human capital and good institutions may hamper expected poverty reduction from developed financial sector through access to financial services. This paper re-examine the role of financial sector on poverty and make contribution to the literature by empirically analyzing the threshold effects and testing for non-linearities in the financial development-poverty relationship based on panels data for sub-Saharan Africa countries. The empirical experience is based on poverty model using data from 42 sub-Saharan Africa countries and covering the period 1980-2012.We employ the System Generalized Method of Moment (GMM) estimator that is appropriate to control country-specific effects and the possible endogeneity of control variables with poverty. Our findings support the view that the relation between financial development and poverty is not linear for Sub-Saharan Africa and points to an inverted U curve type response.

The remainder of the paper is organized as follows. Section 2 reviews the theoretical and empirical literature linking financial development and poverty reduction. Section 3 presents the model and discusses the econometric issues. Section 4 presents data used to implement the model. Section 5 summaries and analyses the empirical results. Section 6 concludes the paper and draws the main economic policy implications.

\section{The Link between Financial Development and Poverty Reduction}

The lack of access to financial services is one of the main factors explaining persistent poverty (Levine, 2008). The role of financial development has been a key debate in poverty reduction strategy. Theory suggests that access to finance allows poor to better investment and education (Jacoby \& Skousfias, 1997; Beegle et al., 2003). Financial development is recognized as a mean that can lead to the reduction of poverty by helping poor to diversify their sources of income through self-employment. The development of financial sector can ease the credit constraint hitherto faced by poor households and which limited their abilities to undertake productive investment. The question of the existence and nature of the link between financial development and poverty has been the subject of considerable interest and debate. However, neither the existing theoretical models nor empirical findings have produced definite conclusion.

Theoretically, financial development can directly contribute to poverty reduction by improving the opportunities for the poor to access formal finance and enables them to achieve a sustainable livelihood (Stiglitz, 1998; Jalilian $\&$ Kirkpatrick, 2002). Financial development can also indirectly reduce poverty and income inequality through enhancing economic growth and the gains from growth are channeled to the poor. One of the way in which financial development enhances economic growth is through the mobilization of funds from inefficient to efficient use. Theory provides, however, conflicting predictions about the impact of financial development on the income of the poor. Singh and Huang (2015) argue that if financial markets were perfect, the availability of finance would allow individuals to fund education, training or business opportunities. In this framework, financial development would contribute to equalize opportunities by reducing the importance of initial wealth and then would favor the poor. But others theories suggest that financial deepening would favor the rich because 
financial institutions operate in settings where complete information is often unavailable. In this context, projects from entrepreneurs that have different probabilities of success are indistinguishable and the information asymmetry requires banks to screen application so as to grant loans only to the most promising projects (Singh, 1992). Finally, the relation between financial development and poverty may be nonlinear. Greenwood and Jovanovic (1990) present a model where income inequality first rises as the financial sector develops but then declines as more people gain access to the system. The financial sector acquires greater capacity and interest to bear the high costs of small credits as it becomes stronger and more competitive (Rajan \& Zingales, 2003).

Like theoretical analyses, empirical investigations are controversial. The evidence pointed that the degree of financial intermediation has a strong and positive impact on the income of the poor (Jalilian \& Kirkpatrick, 2002; Beck et al., 2007; Boukhatem \& Bochra, 2012). Financial development can improve the opportunities for the poor to access formal finance by addressing the causes of financial market failures such as information asymmetry (Stiglitz, 1998). Also, financial development can enable the poor to start microenterprises, which generates more employment and higher income and thereby reduces poverty. Some others findings suggested that financial development may trickle down to the poor trough its positive effect on economic growth because of the positive effect of economic growth on poverty reduction (Ravallion \& Datt, 2002; Fan et al., 2000). Uddin et al. (2014) found that a long-run relationship between financial development, economic growth and poverty reduction exists in Bangladesh and financial development helps to reduce poverty but its effect is not linear. Shabhaz and Rehman (2013) find that financial development causes poverty reduction in Pakistan. For African countries, Quartey (2005), and Odhiambo (2009) reach the same result for Ghana, Zambia and South Africa, respectively.

In contrast, some studies find that financial development does not affect the poor (Dollar \& Kraay, 2002; Fowowe \& Abidoye, 2012). Guillaumont-Jeanneney and Kpodar (2011) find that the contribution of finance in alleviating poverty depends on the transmission channel. For example, their findings suggest that if financial development is measured by the ratio of M3 to GDP, there is a positive relationship between financial development and poverty. But if private credit is used as financial development proxy, the association turns out to be statistically insignificant. They conclude that the poor benefit primarily from the ability of the banking system to facilitate transactions and provide savings opportunities rather than reaping the benefit of greater access to credit.

The benefits of financial development are not automatic and policies aimed at macroeconomic stability and institutional reforms needed to accompany financial development (Singh \& Huang, 2015). Jalilian and Kirkpatrick (2005) and Uddin et al. (2014) found that financial development contributes to poverty reduction and the effect varies with the level of economic development. It seems that there was a certain threshold level of financial development that an economy need to attain before it can get the full indirect benefits and reduce the risks of capital account liberalization.

Some reasons why the literature on financial development-poverty link is inconclusive relate to the fact that different studies use different proxies for financial development and rely on different methodologies. Most empirical studies based on cross-country regressions suggest a significant poverty-reduction effect of financial development, although these have been criticized for poor data quality and inadequate control for the endogeneity (Singh \& Huang, 2015; Uddin et al., 2014; Dhrifi \& Maktouf, 2013; Ho \& Odhiambo, 2011). The inconclusive results can be explained by the fact that financial development almost certainly requires combination with other appropriate policies and linear regression models would not be able to capture such complementary dynamics (Beck et al., 2007).

This paper complements the previous literature on financial development and poverty link by providing new cross-country empirical evidence, taking into account the threshold effects of financial development across Sub-Saharan Africa countries. Moreover, other than just focusing on the direct and indirect effects of financial development shown in the previous literature, the paper also goes further to explore other channels through which financial development can affects poverty reduction, for example governance, trade openness and education.

\section{Model and Econometric Issues}

In the lines of Dollar and Kraay (2002) and Clarke et al. (2006), we estimate a standard poverty model, where poverty depends on financial development, and a set of control variables. The model specification is as follows:

$$
\text { Poverty }_{i, t}=\delta_{1} F D_{i, t}+\delta_{2} X_{i, t}+\vartheta_{t}+\mu_{i}+\varepsilon_{i, t}
$$

where the subscripts $\mathrm{i}$ and $\mathrm{t}$ represent country and time period, respectively, Poverty is the log of poverty 
indicator, $\mathrm{X}$ is the matrix of control variables, FD is a measure of financial development, $\vartheta_{t}$ corresponds to time effects, $\mu_{i}$ denotes unobserved country-specific effects, and $\varepsilon_{i, t}$ the error term.

Following Chang et al. (2009), we then introduce interacting terms to allow the poverty-financial development relationship to vary with some country characteristics (education, governance, trade openness). Now, the regression equation is the following:

$$
\text { Poverty }_{i, t}=\delta_{1} F D_{i, t}+\delta_{2} X_{i, t}+\delta_{3} F D_{i, t} \times x_{i, t}+\vartheta_{t}+\mu_{i}+\varepsilon_{i, t}
$$

where $x_{i, t}$ corresponds alternatively to education, governance and trade openness in the country $\mathrm{i}$ at time $\mathrm{t}$.

To control for country-specific effects and the possible endogeneity of control variables with poverty, we estimate the coefficients of our model by using the System Generalized Method-of-Moment (GMM) estimator developed by Blundell and Bond (1998). To verify the consistency of the GMM estimator, we have to make sure that lagged values of the explanatory variables are valid instruments in the poverty equation. This issue is examined by considering the Hansen test of over-identifying restrictions. The no rejection of the null hypothesis implies that instrumental variables are not correlated with the residual and are satisfying the orthogonality conditions required.

\section{Data and Variables Definitions}

The study works with pooled cross-country and time-series data for forty-two Sub-Saharan Africa countries averaged over five-year period from 1980 to 2012. The choice of the period of study is related to the availability of data on interest variables such as financial development and poverty. The data come from the databases of the World Bank and International Monetary Fund. The dependent variable is poverty indicator, measured by poverty headcount index and poverty gap. We also include a set of control variables that are commonly used in poverty equations.

Poverty. There are many definitions and measures of poverty but the most popular indicator is the poverty headcount index which measures the percentage of population living with per capita consumption or income below the poverty line. It is a measure of absolute poverty. Another popular measure is the poverty gap which takes into account the distance of the poor from the poverty line. This measure characterizes how far below the poverty line lies the average income of the poor and provides some sense of distribution. Unlike the headcount index, this indicator captures a decrease or increase in the income of the poor even when it does not cross the poverty line. As dependent variable, we use the poverty headcount index and the poverty gap considering the $\$ 1.25$ poverty line.

Financial development. Financial development can improve the opportunities for the poor to access formal finance by reducing the cost of lending to small borrowers that may reduce poverty. The well-functioning financial system may enable the poor to access financial services, thereby enabling the poor to achieve a sustainable livelihood. We use the ratio of private credit to GDP (PC/GDP) to measure financial development. This measure of financial development is frequently used in the literature (Ho \& Odhiambo, 2011; Uddin et al., 2014; Le Goff \& Singh, 2014).

Control variables. We also include a set of control variables commonly used in poverty equations overall income per capita (GDP per capita) to capture the contribution of economic development. We expect a negative effect of this variable. We add growth of the consumer price index (Inflation) to control for the macroeconomic instability. We also introduce an indicator of institutional quality. Institutional quality impacts positively economic growth (Asiedu, 2003; Acemoglu et al., 2012) and may reduce poverty (Singh \& Huang, 2015). Institutional quality is captured by a governance index (IGOV) through the average of the six measures of institutions presented by Kaufmann et al. (1999), namely: voice and accountability, political stability and absence of terrorist violence, government effectiveness, regulatory quality, rule of law and control of corruption. We add the trade openness (sum of exports and imports as a share of GDP) to capture the degree of international openness. Finally we add a measure of human capital proxied by the logarithm of gross secondary enrollment rate (WDI, 2014). Education is a key determinant of poverty reduction and we expect a negative effect of this variable.

\section{Empirical Results}

\subsection{Unit Root Tests}

The existence of unit root is tested using tests of Levin et al. (2002), Im et al. (2003) and Maddala and Wu (1999). These tests are performed on the variables of the model in level. The null hypothesis of the presence of a unit root is rejected, if at least two of the three tests simultaneously confirmed that hypothesis. According to the 
statistics of the three types of unit root tests, all the variables of the model are stationary in level (Table A1 of Appendix 1).

\subsection{GMM Estimates}

The GMM estimation results are summarized in Tables 1-2.

The estimate results point out a nonlinear relationship between financial development and poverty and the evidence is robust to alternative poverty measures: headcount index and poverty gap. The results shown the presence of inverted $U$ curve (Laffer Curve of financial development). As the financial sector develops, however, this positive association tends to fade away, the coefficient of the square term being significant and of the opposite sign. These results are consistent with Clarke et al. (2006) and Sing and Huang (2015) and confirm that financial development is significantly associated with higher level of poverty to a threshold and above this threshold, the effect becomes negative. For the headcount index, the threshold is estimated to $10.64 \%$. In other words, financial sector is associated with higher level of poverty up to private credit account for $10.69 \%$ of GPD. According to poverty gap, the findings point out a threshold of 1.19\%, suggesting that financial sector increases poverty gap until private credit account for 1.19\% of GDP (Table 2 of Appendix 1). These results indicate that financial sector can be a relevant driver of poverty reduction for Sub-Saharan Africa countries but needed certain level of its development before it can get the full benefit to reduce poverty.

The results related to the control variables are mostly in line with expectations. The results demonstrate that per capita income has a significant poverty-reduction effect. The negative and significant coefficient of income per capita for headcount index reveals that other things being equal, more developed countries then have lower levels of poverty. Interestingly, the results also show a significant positive effect between income per capita and poverty gap, which could indicate that income inequality is higher in the richer Sub-Saharan Africa countries. The results also indicate that education is negatively correlated with poverty, whether measured by headcount index or the poverty gap, but the effect is not significant for poverty gap. We find a significant negative association between governance and poverty gap. The same effect is found for trade openness. Inflation has no significant effect on poverty. This result is consistent with the study of Le Goff and Sing (2014).

While the first regression only considers financial development effects, we examine next the influence of some structural country characteristics in the financial sector-poverty relationship. The results with the interaction terms are presented in models 2, 3 and 4 of Tables 1-2.

We first test the role of human capital in the financial development-poverty relationship (Model 2). The coefficient of the interaction is negative and significant for the headcount index and the poverty gap equation. The beneficial impact of an increase in financial development is larger when the investment on human capital is stronger. We find that an increase in gross secondary enrollment rate is associated with lower poverty rate. This result is consistent with theoretical models suggesting that the effect of financial development on poverty may depend on the human capital stock.

Model 3 examines whether the relationship between the financial development and the poverty rate may hinge on a country's institutional environment. The results suggest governance significantly enhance the association between financial development and poverty reduction. As we expected, the poor benefit more from financial development in countries with high quality of governance, which allows the emergence of new enterprises, improving the poor income.

Finally, we test whether financial development-poverty relationship would change with the trade openness (Model 4). The coefficient of the interaction term with the trade openness measure is negative and significant for the headcount index and the poverty gap equation. These results suggest that a more developed financial sector is associated with lower levels of poverty when trade is more developed. In other words, more trade openness may allow the poor to benefit more from access to cheaper credit. 
Table 1. Financial development (Private Credit PC) and poverty headcount index in Sub-Saharan Africa-GMM system

\begin{tabular}{|c|c|c|c|c|}
\hline \multicolumn{5}{|c|}{ Poverty headcount $(\log )$} \\
\hline & (1) & (2) & (3) & (4) \\
\hline \multirow[t]{2}{*}{ Inflation $(\log )$} & 0.0045 & 0.0044 & $0.0067 *$ & 0.0056 \\
\hline & $(0.0035)$ & $(0.0036)$ & $(0.0039)$ & $(0.0037)$ \\
\hline \multirow[t]{2}{*}{ Trade openness (log) } & 0.0172 & 0.0179 & 0.0135 & $-0.1500^{*}$ \\
\hline & $(0.0155)$ & $(0.0160)$ & $(0.0169)$ & $(0.0803)$ \\
\hline \multirow[t]{2}{*}{ Igov } & -0.0104 & -0.0108 & $0.1202 * * *$ & -0.0079 \\
\hline & $(0.0105)$ & $(0.0106)$ & $(0.0368)$ & $(0.0109)$ \\
\hline \multirow[t]{2}{*}{ Private credit $(\mathrm{PC})(\log )$} & $0.1405^{* * *} *$ & $0.1362 * *$ & $0.1362 * * *$ & -0.4512 \\
\hline & $(0.0445)$ & $(0.0542)$ & $(0.0478)$ & $(0.2837)$ \\
\hline \multirow[t]{2}{*}{$\mathrm{PC}^{2}$} & $-0.0297 * * *$ & $-0.0296 * * *$ & $-0.0300 * * *$ & 0.0295 \\
\hline & $(0.0085)$ & $(0.0085)$ & $(0.0091)$ & $(0.0293)$ \\
\hline \multirow[t]{2}{*}{ LEdu (log) } & $-0.0292 * * *$ & -0.0324 & $-0.0334 * * *$ & $-0.0313^{* * *}$ \\
\hline & $(0.0066)$ & $(0.0241)$ & $(0.0068)$ & $(0.0069)$ \\
\hline \multirow[t]{2}{*}{ LGdpc $(\log )$} & $-0.0323 * * *$ & $-0.0321 * * *$ & $-0.0307 * * *$ & $-0.0328 * * *$ \\
\hline & $(0.0052)$ & $(0.0052)$ & $(0.0056)$ & $(0.0054)$ \\
\hline \multirow[t]{2}{*}{ PC*Ledu } & & $-0.0272 * * *$ & & \\
\hline & & $(0.0062)$ & & \\
\hline \multirow[t]{2}{*}{ PC*Igov } & & & $-0.0335 * *$ & \\
\hline & & & $(0.0134)$ & \\
\hline \multirow[t]{2}{*}{ PC* Openess } & & & & $-0.6999 * *$ \\
\hline & & & & $(0.3313)$ \\
\hline \multirow[t]{2}{*}{ Constant } & $-0.2658 * * *$ & $-0.2598 *$ & $-0.2296^{*}$ & -0.1083 \\
\hline & $(0.1281)$ & $(0.1372)$ & $(0.1380)$ & $(0.1505)$ \\
\hline Observations & 164 & 164 & 164 & 164 \\
\hline Number of countries & 42 & 42 & 42 & 42 \\
\hline Sargan test & 0.102 & 0.566 & 0.114 & 0.1131 \\
\hline
\end{tabular}

Note. data are averaged over five years. ***Significant at $1 \%$. ** Significant at 5\%. * Significant at 10\%. Standard errors in parentheses.

Table 2. Financial development (Private Credit PC) and poverty gap in Sub-Saharan Africa-GMM-sytem

\begin{tabular}{|c|c|c|c|c|}
\hline \multicolumn{5}{|c|}{ Poverty gap $(\log )$} \\
\hline & (1) & (2) & (3) & (4) \\
\hline \multirow[t]{2}{*}{ Inflation $(\log )$} & 0.0313 & 0.0321 & 0.0341 & $0.0452 * *$ \\
\hline & $(0.0215)$ & $(0.0219)$ & $(0.0216)$ & $(0.0212)$ \\
\hline \multirow[t]{2}{*}{ Trade openness (log) } & $-0.1975^{* *}$ & $-0.2000^{* *}$ & $-0.199 * * 5$ & $-0.5369 * * *$ \\
\hline & $(0.0888)$ & $(0.0978)$ & $(0.0926)$ & $(0.1756)$ \\
\hline \multirow[t]{2}{*}{ Igov } & $-0.1641 * *$ & $-0.1655^{* *}$ & 0.0975 & $-0.1380 *$ \\
\hline & $(0.0756)$ & $(0.0769)$ & $(0.1970)$ & $(0.0753)$ \\
\hline \multirow[t]{2}{*}{ Private credit $(\mathrm{PC})(\log )$} & $0.0205^{* *}$ & $0.0212 * *$ & $0.0212 * *$ & 0.0098 \\
\hline & $(0.0085)$ & $(0.0104)$ & $(0.0088)$ & (0.0099) \\
\hline \multirow[t]{2}{*}{$\mathrm{PC}^{2}$} & $-0.0580^{*}$ & -0.0549 & $-0.0632 * *$ & -0.0490 \\
\hline & $(0.0300)$ & $(0.0380)$ & $(0.0305)$ & $(0.0315)$ \\
\hline \multirow[t]{2}{*}{ LEdu $(\log )$} & 0.00001 & -0.0364 & -0.0606 & $-0.0742 *$ \\
\hline & $(0.00001)$ & $(0.2137)$ & $(0.0442)$ & $(0.0423)$ \\
\hline \multirow[t]{2}{*}{ LGdpc (log) } & $1.2086^{* * *}$ & 0.00001 & $0.1131 *$ & $0.1224 *$ \\
\hline & $(0.3519)$ & $(0.00001)$ & $(0.0644)$ & $(0.0678)$ \\
\hline \multirow[t]{2}{*}{ PC*Ledu } & & $-2.0273 * *$ & & \\
\hline & & $(0.8647)$ & & \\
\hline \multirow[t]{2}{*}{ PC*Igov } & & & $-0.1776^{* *}$ & \\
\hline & & & $(0.0705)$ & \\
\hline \multirow[t]{2}{*}{ PC*Openess } & & & & $-0.0018 *$ \\
\hline & & & & $(0.0009)$ \\
\hline \multirow[t]{2}{*}{ Constant } & -0.0591 & $1.1877 * * *$ & 0.3542 & $1.4236 * *$ \\
\hline & $(0.0424)$ & $(0.4007)$ & $(0.5252)$ & $(0.6894)$ \\
\hline Observations & 164 & 164 & 164 & 164 \\
\hline Number of countries & 42 & 42 & 42 & 42 \\
\hline Sargan test & 0.102 & 0.566 & 0.114 & 0.1131 \\
\hline
\end{tabular}

Note. data are averaged over five years. *** Significant at $1 \%$.** Significant at $5 \%$ * Significant at $10 \%$. Standard errors in parentheses. 


\section{Conclusions}

In this paper, we have tested a poverty model in the context of Sub-Saharan African countries and two measures of poverty: headcount index and poverty gap. Our results suggest that financial development may impact favorably the poverty indicators. However, the effect is not linear and our results show the presence of inverted $\mathrm{U}$ curve and confirm that financial development has a detrimental effect on poverty to a threshold and above this threshold, financial development is associated with less poverty. The no linear relationship between financial development and poverty suggests that the benefits of financial development are not automatic. Then, the poverty effects of financial development may differ according to the development of financial sector. The results then suggest that policies to accompany financial development are needed. These policies would aim at encouraging the quality of institutions, the ability to adjust and learn new skills and the openness of the economy. These policies would then allow resources to be allocated away from less productive activities to more promising ones. Financial development should therefore not be seen in isolation and additional policies will be needed to enhance its impact on poverty reduction strategy. Sub-Saharan African countries should carry on relevant policies such as those that encourage trade openness, allow effective governance and promote human capital accumulation.

This paper provides some interesting findings at the study of financial development and poverty whose can be improved upon. Since informal financial sector is important in Sub-Saharan African countries, future research should work to develop financial development index that will capture the development of both informal and formal financial sector. Being the fact that poverty is multi-dimensional, further empirical studies using multi-dimensional poverty indicators could be carried out to produce more relevant findings.

\section{References}

Acemoglu, D., \& Robinson, J. A. (2012). Why Nations Fail: The Origins of Power, Prosperity, and Poverty (pp. 1-571). Crown Publisers, Crown Publishing Group, a Division of Random House. https://doi.org/10.1355/ae29-2j

Akhter, S., Liu, Y., \& Daly, K. (2010). Cross country evidence on the linkages between financial development and poverty. International Journal of Business and Management, 5.

Asiedu, E. (2003). Debt Relief and Institutional Reform: A Focus on Heavily Indebted Poor Countries. The Quarterly Review of Economics and Finance, 43(3), 614-26. https://doi.org/10.1016/S1062-9769(03)00038-3

Beck, T., Demirguc-Kunt, A., \& Levine, R. (2007). Finance, Inequality and the Poor. Journal of Economic Growth, 12, 27-49. http://dx.doi.org/10.1007/s10887-007-9010-6

Beegle, K., Dehejia, R., \& GAtti, R. (2003). Child labor, crop shocks, and credidti constraints. NBER Working Paper 10088. Cambridge, MA: National Bureau of Economic Research. https://doi.org/10.3386/w10088

Blundell, R., \& Bond, S. (1998). Initial conditions and moment restrictions in dynamic panel data models. Journal of Economics, 87(1), 115-143. https://doi.org/10.1016/S0304-4076(98)00009-8

Boukhatem, J., \& Bochra, M. (2012). Effects directs du développement financier sur la pauvreté: Validation empirique sur un panel de pays à bas et moyen revenu. Mondes en Développement, 160, 133-148. http://dx.doi.org/10.3917/med.160.0133

Chang, R., Kaltani, L., \& Loayza, N. V. (2009). Openness can be good for growth: The role of policy $\begin{array}{llll}\text { complementarities. Journal of Development Economics, } & 90(1), \quad 33-49 .\end{array}$ https://doi.org/10.1016/j.jdeveco.2008.06.011

Clarke, G., Xu, L. C., \& Zou, H. (2003). Financial and income inequality: Test of alternatives theories. World Bank Policy Research Paper, WPS 2984. The World Bank, Washington DC.

Clarke, G., Xu, L. C., \& Zou, H. (2006). Financial and income inequality: What do the data tell us? Southern Economic Journal, 72, 578-596. http://dx.doi.org/10.2307/20111834

Dhrifi, A., \& Maktouf, S. (2013). Financial liberalization and poverty: The Threshold Effect of Financial Development. International Journal of Business and Management Invention, 2(1), 1-10.

Dollar, D., \& Kraay, A. (2002). Growth is good for the poor. Journal of Economic Growth, 7, 195-225. https://doi.org/10.1023/A:1020139631000

Easterly, W., \& Fischer, S. (2001). Inflation and the poor. Journal of Money, Credit and banking, 33(2), 160-178. https://doi.org/10.2307/2673879 
Fan, S., Hazell, P., \& Thorat, S. (2000). Government spending, growth and poverty in rural India. American Journal of Agricultural Economics, 82, 1038-1051. https://doi.org/10.1111/0002-9092.00101

Fowowe, B., \& Abidoye, B. (2012). A quantitative assessment of the effect of financial development on poverty in African countries. Department of Economics, University of Ibadan, Nigeria. http://dx.doi.org/10.1111/j.1467-9957.2012.02302.x

Greenwood, J., \& Jovanovic, B. (1990). Financial Development, Growth, and the Distribution of Income. Journal of Political Economy, 98(5), 1076-1107. http://dx.doi.org/10.1086/261720

Guillaumont-Jeanneney, S., \& Kpodar, K. (2011). Financial development and poverty reduction: Can there be a benefit without cost? Journal of Development Studies, 47(1), 143-163. https://doi.org/10.1080/00220388.2010.506918

Ho, S. Y., \& Odhiambo, M. N. (2011). Finance and poverty reduction in China: An empirical investigation. International Business \& Economic Research Journal, 10, 103-114. https://doi.org/10.19030/iber.v10i8.5382

Honohan, P. (2004). Financial Development, Growth and Poverty: How Close are the link? World Bank Policy Research Working Paper 3203, Washington D.C: World Bank. http://dx.doi.org/10.1596/1813-9450-3203

Im, K. S., Pesaran, M. H., \& Shin, Y. (2003). Testing for Unit Roots in Heterogeneous Panels. Journal of Econometrics, 115(1), 53-74. https://doi.org/10.1016/S0304-4076(03)00092-7

Jacoby, H., \& Skoufias, E. (1997). Risk, financial markets, and human capital. Review of Economic Studies, 64, 311-335. http://dx.doi.org/10.2307/2971716

Jalilian, H., \& Kirkpatrick, C. (2002). Financial development and poverty reduction in developing countries. International Journal of Finance and Economics, 7, 97-108. http://dx.doi.org/10.1002/ijfe.179

Jalilian, H., \& Kirkpatrick, C. (2005). Does financial development contribute to poverty reduction? Journal of Development Studies, 41(4), 636-656. https://doi.org/10.1080/00220380500092754

Kaminsky, G. L., \& Reinhart, C. M. (1999). The Twin Crises: The Causes of Banking and balance-Of-Payments Problems. American Economic Review, 89(3), 473-500. https://doi.org/10.1257/aer.89.3.473

Kaufmann, D., Kraay, A., \& Zoido-Lobaton, P. (1999). Aggregating Governance Indicators. Policy Research Paper 2195, The World Bank. https://doi.org/10.2139/ssrn.188548

King, R. G., \& Levine, R. (1993). Finance and Growth: Schumpeter Might be Right. Quarterly Journal of Economics, 108(3), 717-737. https://doi.org/10.2307/2118406

Le Goff, M., \& Singh, R. J. (2014). Does trade reduce poverty? A view of Africa. Journal of African Trade, 1(2014), 5-14. https://doi.org/10.1016/j.joat.2014.06.001

Levine, A., Lin, C. F., \& Chu, C. (2002). Unit Root Test in Panel: Asymptotic and Finite Sample Properties. Journal of Econometrics, 108(1), 1-24. https://doi.org/10.1016/S0304-4076(01)00098-7

Levine, R. (2005). Finance and Growth: Theory and Evidence. In P. Aghion, \& S. Durlauf (Eds.), Handbook of Economic Growth (Vol. 1, Part A, pp. 865-934).

Levine, R. (2008). Finance and the poor. The Manchester School, 76, 1-13. http://dx.doi.org/10.1111/j.1467-9957.2008.01078.x

Maddala, G. S., \& Wu, S. (1999). A Comparative Study of Unit Root Tests with Panel Data and a New Simple Test. Oxford Bulletin of Economics and Statistics, 61, 631-652. https://doi.org/10.1111/1468-0084.61.s1.13

McKinnon, R. I. (1973). Money and Capital in Economic Development. Washington D.C: Brookings Institution.

Odhiambo, N. M. (2009). Finance-growth-poverty nexus in South Africa: A dynamic causality linkage. Journal of Socio-Economics, 38, 320-325. http://dx.doi.org/10.1016/j.socec.2008.12.006

Pradhan, R. P. (2010). The nexus between finance, growth and poverty in India: The cointegration and causality approach. Asian Social Science, 6, 114-122. https://doi.org/10.5539/ass.v6n9p114

Quartey, P. (2005). Financial sector development, savings mobilization and poverty reduction in Ghana. UNU-WIDER Research Paper No. 2005/71, Helsinki: UNU World Institute for Development Economics Research. http://dx.doi.org/10.4337/9781845424602.00008

Rajan, R. G., \& Zingales, L. (2003). Banks and markets: The changing character of European finance. CEPR Discussion Paper No. 3865, London: Centre for Economic Policy Research. 
http://dx.doi.org/10.3386/w9595

Ravallion, M., \& Datt, G. (2002). Why has economic growth been more pro-poor in some states of India than others? Journal of Development Economics, 68, 381-400. https://doi.org/10.1016/S0304-3878(02)00018-4

Shahbaz, M., \& Rehman, I. U. (2013). Multivariate-based Granger causality between financial development and poverty: The case of Pakistan. MPRA paper No. 50834, Munich. http://dx.doi.org/10.1007/s11135-013-9952-z

Shaw, E. S. (1973). Financial Deepening in Economic Development. New York: Oxford University Press.

Singh, R. (1992). An imperfect information approach to the structure of the financial system. UNCTAD Discussion Paper No. 86, Geneva, UNCTAD.

Singh, R. J., \& Huang, Y. (2015). Financial Deepening, Property Rights, and Poverty: Evidence from Sub-Saharan Africa. Journal of Banking and Financial Economics, 1(3), 130-151. https://doi.org/10.7172/2353-6845.jbfe.2015.1.6

Stiglitz, J. (1998). The role of the state in financial markets. In M. Bruno, \& B. Pleskovic (Eds.), Proceedings of the World Bank Annual Conference on Development Economic (pp. 19-52). World Bank, Washington DC.

Uddin, G. S., Shahbaz, M., Arouri, M., \& Teulon, F. (2014). Financial development and poverty reduction nexus: A cointegration and causality analysis in Bangladesh. Economic Modelling, 36, 405-412. https://doi.org/10.1016/j.econmod.2013.09.049

\section{Appendix 1}

\section{Panel Unit root test and threshold effects}

Table A1. Panel unit root test

\begin{tabular}{cccc}
\hline & & Niveau & MW \\
\cline { 2 - 4 } Variables & LLC & IPS & $709.39^{* * *}$ \\
lpovhead & $-0,004^{* * *}$ & -0.8743 & $(0.000)$ \\
& $(0.000)$ & $(0.1910)$ & $667.23^{* * *}$ \\
lpovgap & 3.3706 & $-2.760^{* * *}$ & $(0.0000)$ \\
& $(0.9996)$ & $(0.0029)$ & $235.122^{* * *}$ \\
linf & $-0,01^{* * *}$ & $-11.235^{* * *}$ & $(0.000)$ \\
& $(0.000)$ & $(0.000)$ & $10.746^{* * *}$ \\
lopeness & $-8.9230^{* * *}$ & 1.5357 & $(0.000)$ \\
& $(0.000)$ & $(0.9377)$ & $226.75^{* * *}$ \\
igov & $-37.0912^{* * *}$ & -0.7361 & $(0.000)$ \\
& $(0.000)$ & $(0.2308)$ & $378.03 * * *$ \\
lpc & $-81.0326^{* * *}$ & $-20.925^{* * *}$ & $(0.0000)$ \\
& $(0.0000)$ & $(0.0000)$ & $199.61^{* * *}$ \\
ledu & $-12.3771^{* * *}$ & 0.2986 & $(0.0000)$ \\
\end{tabular}

Note. Standard errors in parentheses; ***,**,* specify that coefficients are statistically significant at the $1 \%, 5 \%$ and $10 \%$ levels.

Source : Author calculations with data provided.

Table A2. Testing threshold effects

\begin{tabular}{lc}
\hline & Private Credit (PC) \\
\hline poverty incidence & 10,64 \\
poverty gap & 1,193 \\
\hline
\end{tabular}

Note. the thresholds values are in percentage of GDP. 


\section{Appendix 2.}

List of countries in the sample

\begin{tabular}{ccc}
\hline Country & Country & Country \\
\hline Angola & Gabon & Niger \\
Benin & Gambia, The & Nigeria \\
Botswana & Ghana & Rwanda \\
Burkina Faso & Guinea & Senegal \\
Burundi & Guinea-Bissau & Seychelles \\
Cameroon & Kenya & Sierra Leone \\
Cape Verde & Lesotho & South Africa \\
Central African Republic & Liberia & Sudan \\
Chad & Madagascar & Swaziland \\
Comoros & Malawi & Tanzania \\
Congo, Dem. Rep. & Mali & Togo \\
Congo Rep. & Mauritania & Uganda \\
Cote d'Ivoire & Mauritius & Zambia \\
Ethiopia & Mozambique & Zimbabwe \\
\hline
\end{tabular}

Source: Author

\section{Copyrights}

Copyright for this article is retained by the author(s), with first publication rights granted to the journal.

This is an open-access article distributed under the terms and conditions of the Creative Commons Attribution license (http://creativecommons.org/licenses/by/4.0/). 